\title{
A METHOD OF TESTING IMPLANTED CARDIAC PACEMAKERS
}

\author{
BY \\ LAWRENCE KNUCKEY, RAYMOND MCDONALD, AND GRAEME SLOMAN \\ From the Department of Medical Electronics and Cardiac Department, Royal Melbourne Hospital, \\ Victoria, Australia
}

Received October 14, 1964

In some patients with complete heart block electrical pacing has become an accepted form of treatment, and this has been well reviewed (Chardack, Gage, and Greatbatch, 1960; Chardack 1964; Zoll et al., 1961; Portal et al., 1962). The quoted battery life of pacemakers available comercially is from 2 to 5 years. However, experience with our first 10 cases has shown that earlier replacement of the units is sometimes necessary because of premature battery failure and either gradual or sudden failure of another component. These failures cause changes in one or more of the following output characteristics of the pacemaker: rate, amplitude, and pulse width. Measurement of these characteristics is easily made with the pacemaker outside the body, but after the unit is implanted this presents some difficulty. Pulse rate of the unit can be obtained from the electrocardiogram, but output voltage and pulse width are more difficult to measure. One commercial model* provides two subcutaneous testing electrodes to which needles can be attached under local anæsthetic, but it is possible for these wires to break while the unit is functioning correctly (Parsonnet et al., 1963).

The standard electrocardiogram from a patient with an implanted pacemaker shows the stimulating pulses (Fig. 1), but their wave form is not accurately reproduced because of the limited frequency response of the recorder. However, if the electrocardiogram is viewed on a calibrated cathode ray oscilloscope with an adequate frequency response, and with the time-base sweep triggered from each pulse, measurement can be made on the amplitude and width of these pulses in any particular lead (Fig. 2). The wave form of the pulse is a replica of the current output wave form of the pacemaker. Our studies with animals have confirmed that the amplitude in a particular lead is directly proportional to the amplitude of the stimulating pulse (Fig. 3). The amplitude was found to be in the range 0-350 $\mathrm{mV}$ depending on the angle between the dipole of the stimulating electrodes and the electrocardiogram lead. The amplitude varied up to $20 \mathrm{mV}$ with respiration, and also varied up to 25 per cent depending on posture.

\section{SUBJECTS AND METHOD}

Ten patients with implanted pacemakers have been studied at intervals of from 2 to 8 weeks after insertion of the units (Table I). With the patient lying in the standard electrocardiographic position, german silver electrodes were attached to the limbs after careful preparation. The right leg was earthed, and the other electrodes (Fig. 4) were connected via a lead selector to a calibrated differential input oscilloscope $\dagger$.

\footnotetext{
* Medtronics pacemaker-Models 5870 and 5860.

$\dagger$ Tektronix types 502 and 564.
} 


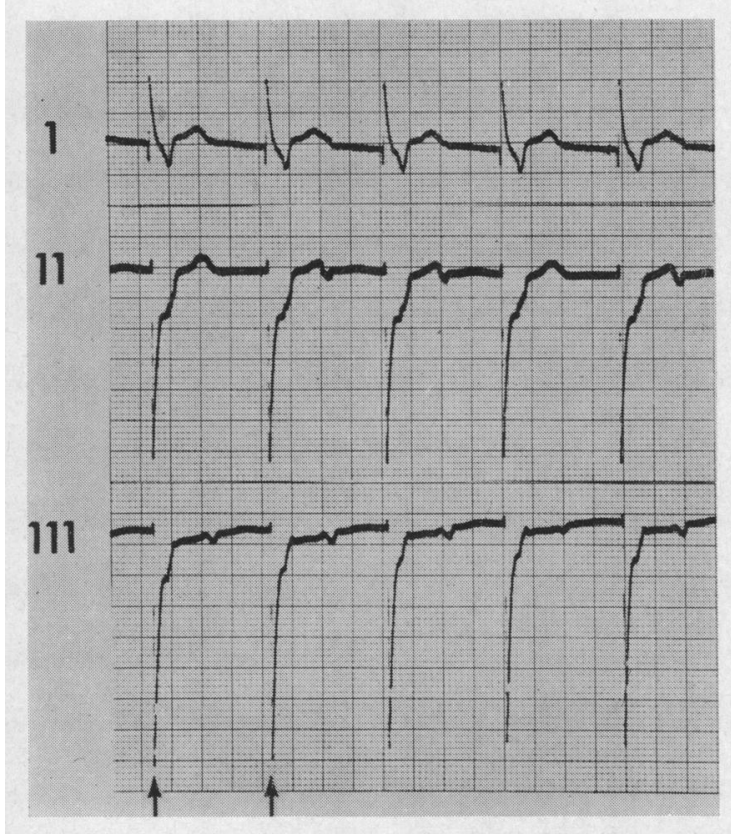

FIG. 1-Electrocardiographic leads I, II, and III from a patient with an implanted pacemaker using unipolar stimulation. The arrows show the small pulse preceding each ventricular complex. The pulses in leads II and III are more than $100 \mathrm{mV}$ amplitude but are not accurately reproduced because of the limited frequency response of the recorder.

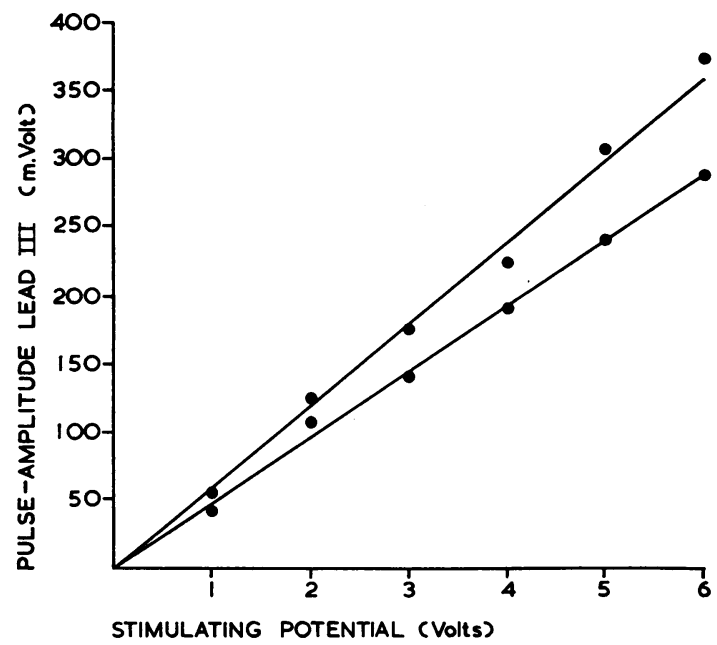

FIG. 3.-Relationship between the amplitude of the pulse from the stimulating electrodes seen in lead III and the actual stimulating potential in an anæsthetized dog with a unipolar stimulating elec. trode system. Maximum and minimum points show the amplitude variation with respiration.

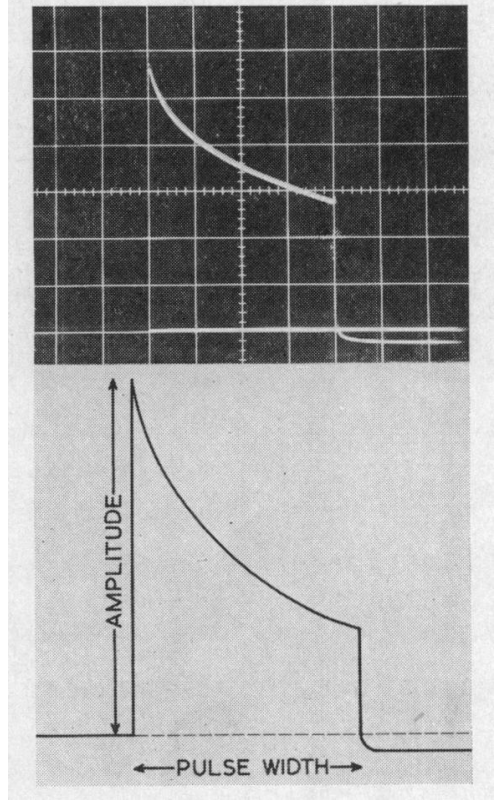

FIG. 2.-Photograph from the screen of a cathode ray oscilloscope showing the pulse from unipolar pacing electrodes seen in lead III of the electrocardiogram. The horizontal speed has been increased to 0.5 millisecond per division, and the vertical scale is $50 \mathrm{mV}$ per division.

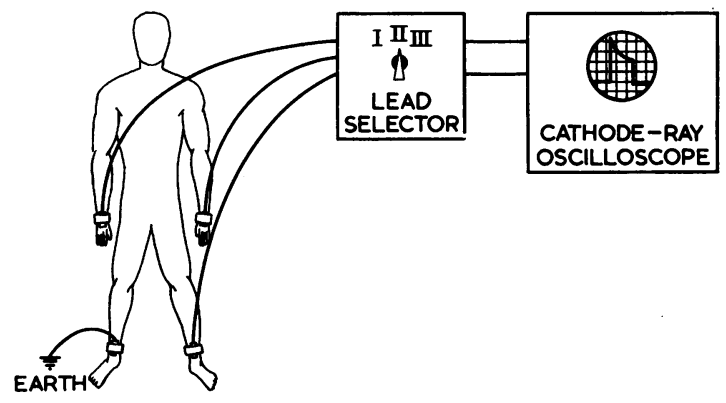

Fig. 4.-Electrocardiograph electrodes and lead selector connected to a differential input cathode ray oscilloscope. The horizontal sweep was set to trigger from the pacemaker pulses, and the amplitude and pulse width were measured from leads I, II, and III in turn. 
TABLE

Data Relating to Pacemakers in Ten Patients

\begin{tabular}{|c|c|c|c|c|c|}
\hline $\begin{array}{l}\text { Case } \\
\text { No. }\end{array}$ & Indication & $\begin{array}{l}\text { Date of } \\
\text { implant }\end{array}$ & $\begin{array}{l}\text { Type of } \\
\text { pacemaker }\end{array}$ & $\begin{array}{l}\text { Longevity of } \\
\text { unit (mth.) }\end{array}$ & Outcome \\
\hline 1 & $\begin{array}{l}\text { Complete } \\
\text { heart-block; } \\
\text { Stokes-Adams } \\
\text { attacks }\end{array}$ & May 1961 & $\begin{array}{l}\text { Elema } 137 \\
\text { bipolar } \\
\text { electrodes }\end{array}$ & - & $\begin{array}{l}\text { Sudden death probably due to ven- } \\
\text { tricular fibrillation } 2 \text { mth. after } \\
\text { implant }\end{array}$ \\
\hline \multirow{4}{*}{2} & \multirow{3}{*}{$\begin{array}{l}\text { Complete } \\
\text { heart-block; } \\
\text { Stokes-Adams } \\
\text { attacks }\end{array}$} & $\begin{array}{c}\text { April } \\
1962\end{array}$ & $\begin{array}{l}\text { Elema } 137 \\
\text { bipolar } \\
\text { electrodes }\end{array}$ & 12 & $\begin{array}{l}\text { Unit removed because of battery } \\
\text { failure }\end{array}$ \\
\hline & & $\begin{array}{l}\text { April } \\
1963\end{array}$ & $\begin{array}{l}\text { Elema } 137 \\
\text { bipolar } \\
\text { electrodes }\end{array}$ & 12 & $\begin{array}{l}\text { Unit removed because of } 14 \% \text { rise in } \\
\text { rate and } 45 \% \text { decrease in pulse- } \\
\text { width }\end{array}$ \\
\hline & & $\begin{array}{c}\text { April } \\
1964\end{array}$ & $\begin{array}{l}\text { St. George's } \\
\text { unipolar } \\
\text { electrodes }\end{array}$ & - & $\begin{array}{l}\text { Unit still operating satisfactorily after } \\
4 \mathrm{mth} \text {. }\end{array}$ \\
\hline & \multirow{3}{*}{$\begin{array}{l}\text { Complete } \\
\text { heart-block; } \\
\text { Stokes-Adams } \\
\text { attacks }\end{array}$} & Aug. & $\begin{array}{l}\text { Elema } 137 \\
\text { bipolar } \\
\text { electrodes }\end{array}$ & 6 & $\begin{array}{l}\text { Unit removed because of failure, } \\
\text { assumed due to battery failure }\end{array}$ \\
\hline 3 & & $\begin{array}{l}\text { Feb. } \\
1963\end{array}$ & $\begin{array}{l}\text { Elema } 137 \\
\text { bipolar } \\
\text { electrodes }\end{array}$ & 3 & $\begin{array}{l}\text { Unit removed because of infection, } \\
36 \% \text { rise in rate; } 20 \% \text { rise in pulse- } \\
\text { width; patient maintained on elec- } \\
\text { trode catheter. }\end{array}$ \\
\hline & & $\begin{array}{r}\text { March } \\
1963\end{array}$ & $\begin{array}{l}\text { Elema } 137 \\
\text { bipolar } \\
\text { electrodes }\end{array}$ & $4 \frac{1}{2}$ & $\begin{array}{l}\text { Unit removed because of } 23 \% \text { rise in } \\
\text { rate }\end{array}$ \\
\hline 4 & $\begin{array}{l}\text { Complete } \\
\text { heart-block; } \\
\text { Stokes-Adams } \\
\text { attacks }\end{array}$ & $\begin{array}{l}\text { July } \\
1963\end{array}$ & $\begin{array}{l}\text { Elema } 137 \\
\text { bipolar } \\
\text { electrodes }\end{array}$ & - & $\begin{array}{l}\text { Unit exteriorized after } 3 \frac{1}{2} \text { mth. be- } \\
\text { cause of infection; pacing con- } \\
\text { tinued through same wires }\end{array}$ \\
\hline 5 & $\begin{array}{l}\text { Complete } \\
\text { heart-block; } \\
\text { Stokes-Adams } \\
\text { attacks }\end{array}$ & $\begin{array}{l}\text { March } \\
1963\end{array}$ & $\begin{array}{l}\text { St. George's } \\
\text { unipolar } \\
\text { electrodes }\end{array}$ & - & $\begin{array}{l}\text { Death } 2 \text { wk. after implant due to } \\
\text { pacing failure associated with puru- } \\
\text { lent pericarditis }\end{array}$ \\
\hline \multirow[t]{2}{*}{6} & \multirow{2}{*}{$\begin{array}{l}\text { Complete } \\
\text { heart-block; } \\
\text { Stokes-Adams } \\
\text { attacks }\end{array}$} & $\int_{1963}^{\text {May }}$ & $\begin{array}{l}\text { St. George's } \\
\text { unipolar } \\
\text { electrodes }\end{array}$ & 9 & $\begin{array}{l}\text { Unit removed because of } 70 \% \text { rise in } \\
\text { rate and } 40 \% \text { decrease in amplitude } \\
\text { in leads II and III }\end{array}$ \\
\hline & & $\begin{array}{r}\text { March } \\
1964\end{array}$ & $\begin{array}{l}\text { St. George's } \\
\text { unipolar } \\
\text { electrodes }\end{array}$ & - & $\begin{array}{l}\text { Death } 2 \text { days post-operatively; pacing } \\
\text { failure due to unknown cause }\end{array}$ \\
\hline 7 & $\begin{array}{l}\text { Complete } \\
\text { heart-block; } \\
\text { heart failure }\end{array}$ & July 1963 & $\begin{array}{l}\text { St. George's } \\
\text { unipolar } \\
\text { electrodes }\end{array}$ & - & Unit still operating satisfactorily \\
\hline 8 & $\begin{array}{l}\text { Complete } \\
\text { heart-block; } \\
\text { Stokes-Adams } \\
\text { attacks }\end{array}$ & July 1963 & $\begin{array}{l}\text { St. George's } \\
\text { unipolar } \\
\text { electrodes }\end{array}$ & - & Unit still operating satisfactorily \\
\hline 9 & $\begin{array}{l}\text { Complete } \\
\text { heart-block; } \\
\text { Stokes-Adams } \\
\text { attacks }\end{array}$ & Dec. 1963 & $\begin{array}{l}\text { St. George's } \\
\text { unipolar } \\
\text { electrodes }\end{array}$ & - & Unit still operating satisfactorily \\
\hline 10 & $\begin{array}{l}\text { Complete } \\
\text { heart-block; } \\
\text { Stokes-Adams } \\
\text { attacks }\end{array}$ & June 1964 & $\begin{array}{l}\text { St. George's } \\
\text { unipolar } \\
\text { electrodes }\end{array}$ & - & Unit still operating satisfactorily \\
\hline
\end{tabular}



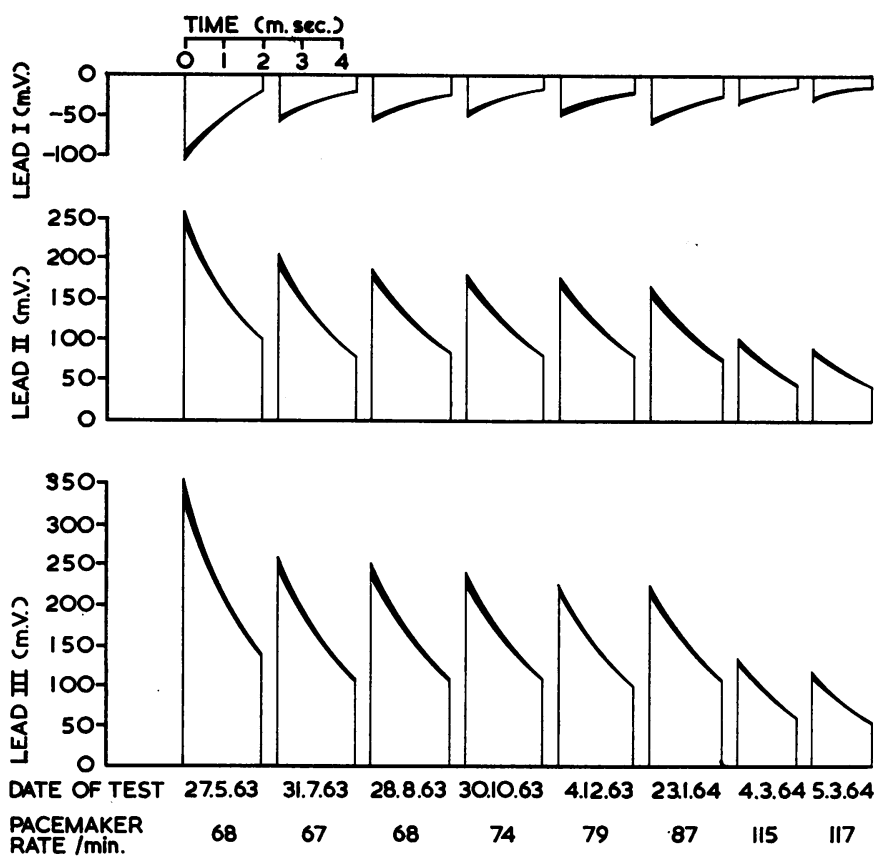

FIG. 5.-Case 6. Results of 8 tests over a period of 10 months on a patient with an implanted pacemaker using unipolar stimulation. The wave form details were recorded at each test, and the amplitude variations due to respirations are shown in black.

The horizontal sweep was set to trigger from the pacemaker pulse and the amplitude and pulse-width were recorded from leads I, II, and III. The amplitude was measured during normal breathing, held inspiration and held expiration, and the rate was measured. All tests on one patient over a period of 10 months are shown in Fig. 5. Fig. 6 shows a more convenient method of displaying the progressive results.

Before each test the horizontal calibration of the cathode ray oscilloscope was checked by using a crystal-controlled Time-mark generator*, and the vertical scale was checked against a standard voltage cell.

\section{RESULTS}

The results of tests on four patients are reported to demonstrate typical findings from units with unipolar and bipolar stimulating electrodes.

\section{CASE REPORTS}

Case 2. A 64-year-old woman with complete heart block had recurrent Stokes-Adams attacks which could only be controlled by a right ventricular electrode catheter. An Elema pacemaker (type 137) was implanted using a bipolar electrode system. No tests were done on this unit. Because of premature battery failure it was replaced after 12 months with a second Elema unit which was tested 4 days after implant and then at intervals of 4 to 14 weeks. As seen in Fig. 7, the rate fell considerably for about 5 months and then increased progressively. Over the first 4 months the pulse width remained constant but then decreased progressively. The pulse amplitude in all leads was in the range $0-60 \mathrm{mV}$ and no over-all change was detected. Because of the continual decrease in pulse width and increase in pulse rate, the unit was removed 12 months after implant. On examination the pulse width was found to have fallen to the value indicated before removal. A new pacemaker inserted at that time has remained stable.

Case 6. A 68-year-old diabetic woman had complete heart block and Stokes-Adams attacks which failed to respond to medical treatment. A St. George's pacemaker with unipolar electrodes was implanted

* Tektronix type 180-A Time-mark generator. 


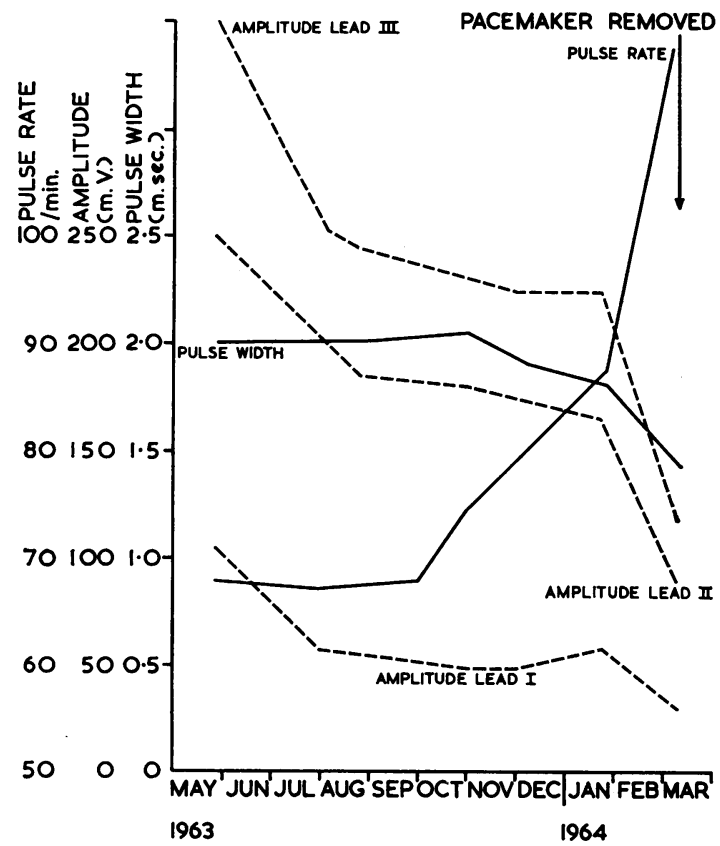

Fig. 6.-Case 6. A patient with unipolar stimulating electrodes. Pulse rate, pulse width, and average amplitude in leads I, II, and III plotted against time. The pacemaker was removed after 10 months because of the rise in rate and 60 per cent decrease in amplitude in all leads.

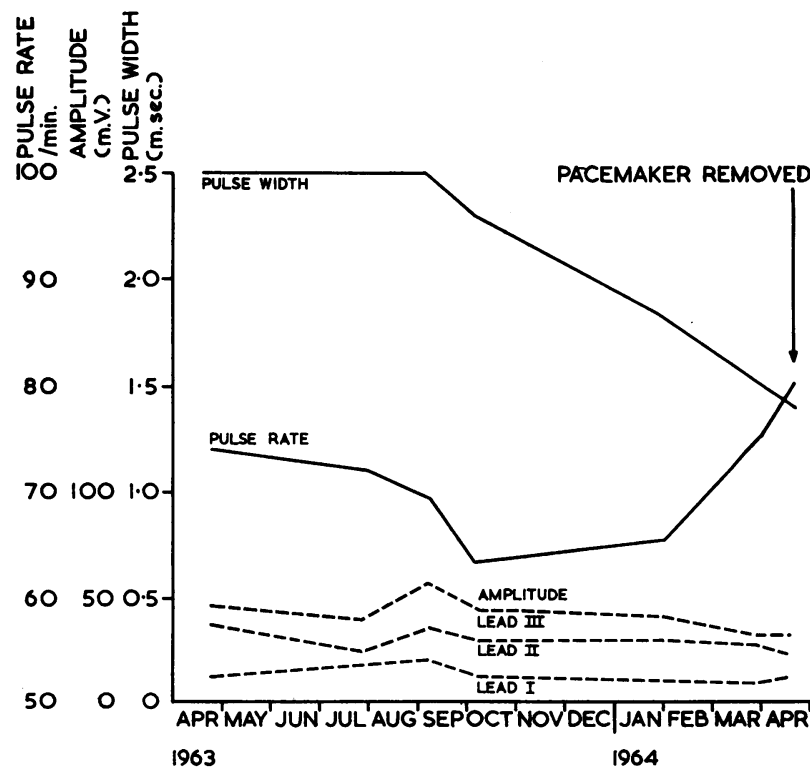

FIG. 7.-Case 2. A patient with bipolar stimulating electrodes. Pulse rate, pulse width, and average amplitude in leads I, II, III plotted against time. The pacemaker was removed after 12 months because of the continual reduction in pulse width since September 1963. in June 1963. The unit was tested soon after implant and then at intervals of from 4 to 8 weeks (see Fig. 6). The pulse amplitude in all leads fell considerably over the first 8 weeks, remained relatively constant until 24 weeks, and then fell suddenly to 60 per cent by 37 weeks. The rate began to increase 16 weeks after implant and by 37 weeks had reached 115 a minute. The pulse width began to decrease 20 weeks after implant and by 37 weeks had decreased by 25 per cent. The unit was removed 37 weeks after implant and tested. The output voltage amplitude was found to have fallen to 60 per cent of the original value and the pulse width had decreased by 25 per cent.

Case 7. A 67-year-old man with complete heart block and recurrent syncopal attacks was treated in August 1963, by insertion of a St. George's pacemaker with unipolar electrodes. The rate decreased over the first 3 months, returned to approximately the original value in the next 3 months, and then decreased again (see Fig. 8). The pulse width increased steadily after implant. The pulse amplitude decreased over the first 3 months and then remained relatively constant, and the unit is continuing to operate satisfactorily.

Case 8. A 64-year-old man was treated for complete heart block by implanting a St. George's pacemaker with unipolar electrodes. The pulse rate was relatively constant over the first three months but then increased slightly (Fig. 9). The pulse amplitude in leads II and III increased over the first 2 weeks, returned to its original value over the next 2 weeks, and has remained relatively constant for 12 months. The unit is continuing to operate satisfactorily.

\section{Discussion}

Measurement of the pacemaker pulse in any electrocardiographic lead, in a patient with either unipolar or bipolar stimulating electrodes, will show the width of the stimulating pulse. Any change in pulse width is an indication of change in pacemaker operation and must be regarded as significant. Large changes in pulse width are important because of the danger of loss of stimulation below about 0.5 millisecond and the risk of ventricular fibrillation with long pulses (Race, 


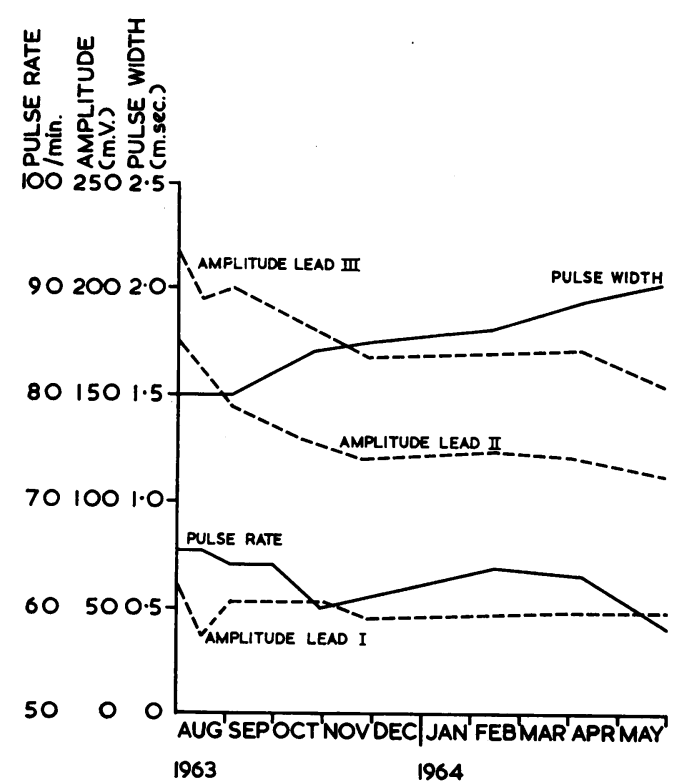

FIG. 8.-Case 7. A patient with unipolar stimulating electrodes. The pulse rate varied considerably over the 10 months shown, the pulse width increased continually, but after the initial changes no over-all trend in amplitude occurred. The unit continues to operate satisfactorily.

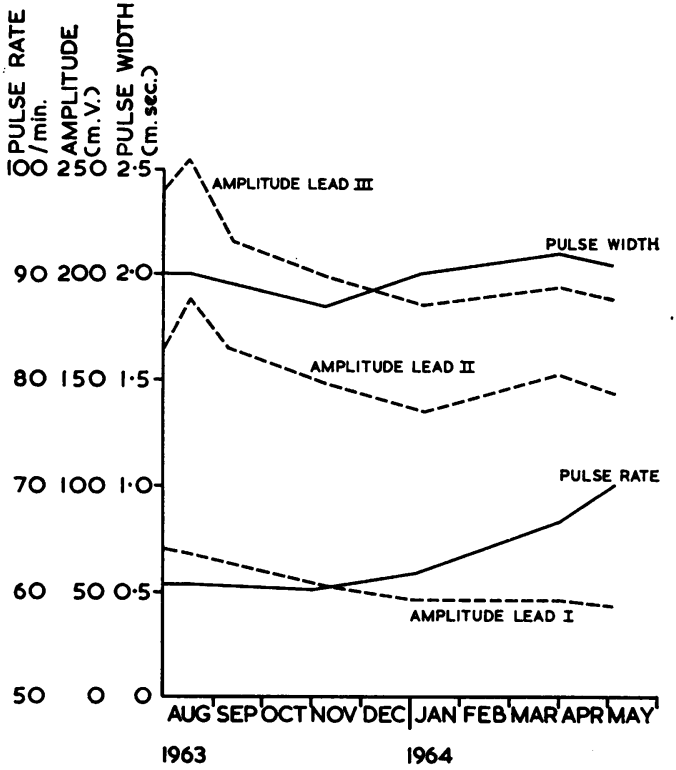

FIG. 9.-Case 8. A patient with unipolar stimulating electrodes. The pulse width varied and the rate gradually increased over the 10 -month period, but after the initial changes no over-all trend in amplitude occurred. The unit is continuing to operate satisfactorily.

Stirling, and Emery, 1963). Case 2 demonstrates the situation where the pulse width from a unit continually narrowed, while the rate increased (Fig. 7). These two variations strongly suggested failure of a component affecting both the width and rate of the output pulses. The unit was removed and on investigation the pulse width measurement was found to have been correct.

It is important to know if any change has occurred in the amplitude of the stimulating pulse, especially in the case of the pacemaker losing control of ventricular action. Though our experience has shown that the amplitude of the pulse in any lead is directly proportional to the amplitude of the stimulating potential, it changes by about 10-15 per cent from week to week with constant stimulating potential. This is most pronounced in the first 8 weeks following implant and is seen best in Cases 6, 7, and 8 . When the batteries are new and the output from the pacemaker can be assumed constant, these initial variations are due to changes in the tissues around the electrodes following suturing. This would cause changes in the electrical field in the patient. The long-term variations in pulse amplitude are poorly understood but are probably due to physical changes in the patient. We took the over-all trend of pulse amplitude, not fluctuations, as an indication of change in stimulating potential.

In the patients with unipolar stimulation (Cases 6, 7, and 8) a long vertical dipole was formed in the body by the electrodes, the negative electrode on a ventricle and the indifferent electrode under the rectus abdominus muscle. Large voltages $(100-300 \mathrm{mV})$ were produced in the vertical leads II and III, and small voltages between the arms in lead I. Patients with bipolar electrode systems had pulse amplitudes in the range $0-60 \mathrm{mV}$ in all leads because of the short dipole formed on the heart by the two ventricular electrodes.

In Case 6 the amplitude in leads II and III decreased to 60 per cent from a relatively steady value over the five months from August 1963 to January 1964. On removal of the unit the output 
voltage was found to have fallen to 60 per cent of the original value. Thus we were able to confirm that a relatively large decrease in amplitude in leads II and III together, with a unipolar electrode system, is reliable evidence of a drop in output voltage amplitude.

In Case 2 (a patient with bipolar electrodes), the pulse amplitude was, at the most, twice as large as the deviation due to respiration and week-by-week changes. Thus the small pulses from a bipolar system do not give a good indication of stimulating potential.

Since both systems of electrode placement will give satisfactory stimulation, we now consider it preferable to use a unipolar system witn the indifferent electrode well away from the heart, because this system gives reliable indication of changes in stimulating pulse amplitude. These measurements, with that of pulse rate, give good criteria for assessing the condition of implanted pacemakers. If the circuit of the unit is known it should be possible to diagnose individual faulty components.

\section{SUMMARY}

Ten patients with implanted pacemakers have been studied at regular intervals, and 4 are reported.

A simple procedure for testing implanted pacemakers has been developed. It consists of measuring the stimulating pulses in the standard electrocardiographic leads when displayed on a cathode ray oscilloscope.

Though the method can be used with unipolar or bipolar electrode systems, more information can be obtained from a unipolar system.

We wish to thank Mr. I. H. McConchie, Mr. J. I. Hayward, and Mr. L. Grigg for implanting the pacemakers and for their interest and support of the project.

\section{REFERENCES}

Chardack, W. M. (1964). Heart block treated with an implantable pacemaker. Progr. cardiovasc. Dis., 6, 507.

-, Gage, A. A., and Greatbatch, W. (1960). A transistorized, self-contained, implantable pacemaker for the longterm correction of complete heart block. Surgery, 48, 643.

Parsonnet, V., Gilbert, L., Zucker, I. R., and Asa, M. M. (1963). Complications of the implanted pacemaker. J. thorac. cardiovasc. Surg., 45, 801.

Portal, R. W., Davies, J. G., Leatham, A., and Siddons, A. H. M. (1962). Artificial pacing for heart-block. Lancet, 2, 1369.

Race, D., Stirling, G. R., and Emery, P. (1963). Electrical stimulation of the heart. Ann. Surg., 158, 100.

Zoll, P. M., Frank, H. A., Zarsky, L. R. N., Linenthal, A. J., and Belgard, A. H. (1961). Long-term electrical stimulation of the heart for Stokes-Adams disease. Ann. Surg., 154, 330. 